\title{
Paula Melton
}

\section{Essays at Anne Carson's Glass, Irony and God}

$$
\text { ESSAY, an attempt. }(F .,-L .,-G k .)^{1}
$$

"Essay" in the poem "The Glass Essay" designates not autobiography but effort: "It pains me to record this,// I am not a melodramatic person" (9). "Glass" describes not clarity but circuitousness: distracted reflections deflect the speaker from love and her ex-love, Law. Emily Brontë, the speaker's "favorite author," doubles as "my main fear, which I mean to confront" (1). Confrontation, by way of retreat, leads to this confrontation:

Everything I know about love and its necessities

I learned in that one moment

when I found myself

thrusting my little burning red backside like a baboon at a man who no longer cherished me. (12)

She backs into her last intercourse with Law as she backs into her pained epiphany. In this Looking-Glass Land, you pursue what you desire by turning from the reflective pane, walking directly away. It is hard to get used to.

-O.F., essai, a trial.

"The Truth About God" will out. He pleads No Contest. Besides, he is incontestable. He cannot help himself: "Sometimes God will drop a fit on you" (40). Drop. God, subject to gravity, is as impersonal:

\footnotetext{
${ }^{1}$ The italicized headings together compose the etymology of the word "essay" as given by the Rev. J. Walter Skeat in his Concise Etymological Dictionary of the English Language.
} 
Don't take it meanly.

Because the outer walls of God are glass.

I see a million souls clambering up the walls on the inside to escape God who is burning,

untended. (40)

Untended and unintentional, God doesn't mean. That is why God's name "is an adverb . . . a one-way street that goes everywhere you are" (4344). Neither subject nor object of our going and coming, God modifies them. Not the unspeakable WHO AM but the unshakeable HOW DO.

-Lat. exagium, weighing, a trial of weight. —Gk. $\varepsilon \xi \alpha \gamma \nu \mathrm{v}, \ldots$. a weighing.

"TV is a condition of weightless balance, like a game./ But TV is not a game" (60). TV, where play is work and work is play, undermines the difference between things that are subject to gravity and things that seem subject to gravity.

"TV uses for 'grave' the word 'sign', like Homer" (62). $\Sigma \eta \mu \alpha$, "sign" or "marker," denotes "grave” by synechdoche. "TV Men," dead people living as dead in the remarks and reruns of the living, unminds the difference between grave and marker. And the flesh became TV and dwelt.

-Gk. $\varepsilon \xi \alpha \gamma \varepsilon \imath$, to lead out, export merchandise.

A journey, for example,

begins with a voice

calling your name out

behind you.

This seems a convenient arrangement.

How else would you know it's time to go?

On the other hand,

Who is it? (75) 
It is dread. The one it calls, the traveler of "The Fall of Rome: A Traveller's Guide," does not turn around. He flies.

To Rome, where he speaks as a stranger. Book of stranger's incantations in hand, he can confront the caller:

You are welcome.

You are very welcome.

It is two

in the morning.

I would like to speak to the chief of police.

There is a black planet speeding toward us. (94)

At last, in Rome, at home-for now-with dread.

-Gk. $\varepsilon \xi$, out; and $\alpha \gamma \varepsilon \imath$, to lead. See Agent.

In "The Book of Isaiah," prophesying meets Dick and Jane. See God's agent:

What is an idol?

An idol is a useless sacrifice, said Isaiah.

But how do we know which ones are useless? asked the nation in its genius. ...

Our life is camera obscura, said Isaiah, do you know what that is? . . .

You can hold up anything you like in front of that pinhole, said Isaiah,

and worship it on the opposite wall.

Why worship an image? asked the nation.

Exactly, said Isaiah. . . . 
So what about Isaiah's pinhole? (110-111)

God's agent is questionable. God's agent is questionable that His agency might be unquestionable.

For the sense, see Exact, Examine.

For the senses see, exact, examine.

For the sense, see sex.

For the sound, see "The Gender of Sound."

For the sounds sound.

"And it becomes important at this point to distinguish sound from language" (128). "It is an axiom of ancient Greek and Roman medical theory and anatomical discussion that women have two mouths" (131). "The doubling and interchangeability of mouth engenders a creature in whom sex is cancelled out by sound and sound is cancelled out by sex" (136). Before they came together she was found to be with child. And the Word was with God.

See sound. See glass: see irony: see God: sound glass.

Resound. Revise. 